\title{
Acute and Subacute Toxicity Study of Methanolic Extract of ceiba pentandra (Linn.) Gaertn. on Rats
}

\author{
B. Gandhare ${ }^{1 *}$, S. Kavimani ${ }^{2}$, and B. Rajkapoor ${ }^{3}$ \\ ${ }^{1}$ Department of Pharmacology, Karapagam University, Coimbatore-641021, India \\ ${ }^{2}$ Department of Pharmacology, Mother Theresa Institute of Health Sciences, Puducherry-605006, \\ India \\ ${ }^{3}$ Department of Pharmacology, Dayananda Sagar College of Pharmacy, Bangalore-560078, India
}

Received 4 September 2012, accepted in revised form 11 March 2013

\begin{abstract}
The purpose of toxicity testing is to provide adequate database to make decisions concerning the toxicology properties of chemical and commercial products. In some situations, the purpose is to decide whether a material will be safe. Under the conditions of expected use in other situations, the objective is to establish the safe limits in condition of use. The methanolic extract of ceiba pentandra was evaluated for acute and subacute toxicity in adult Wistar rats. For the study of acute toxicity, the methanol extract of roots of C. pentandra (MCP) was given separately in various doses $(50,500,1000,2000 \mathrm{mg} / \mathrm{kg}$ ) by oral route. The results showed no signs of toxicity such as general behavior change, mortality, or change in gross appearance of internal organs. Subacute toxicity was studied by daily oral doses 100,400 and $750 \mathrm{mg} / \mathrm{kg}$ (low dose, intermediate dose and high dose) orally for 28 days. The results showed no abnormalities in treated groups as compared to the controls. Although significantly different, all of the values were within normal limits. Neither gross abnormalities nor histopathological changes were observed.
\end{abstract}

Keywords: Acute toxicity; Subacute toxicity; ceiba pentandra.

(C) 2013 JSR Publications. ISSN: 2070-0237 (Print); 2070-0245 (Online). All rights reserved.

doi: http://dx.doi.org/10.3329/jsr.v5i2.11800 J. Sci. Res. 5 (2), 315-324 (2013)

\section{Introduction}

Various parts of the ceiba pentandra are reputed in indigenous medicine. The roots are stimulant, tonic diuretic, emetic and antispasmodic. They have hypoglycemic effect and are used in diabetes, dysentery and gonorrhoea. The young leaves are emollient; decoction of the leaves is used to wash hair. The flowers are demulcent and useful in lochiorrhoea. A decoction of flower is taken as laxative. The bark is emetic, diuretic, astringent and febrifuge. The unripe pods are astringent and demulcent, useful in vertigo and migraine.

\footnotetext{
*Corresponding author: bhushan_gandhare@ rediffmail.com
} 
In Nigeria the seed oil is used in rheumatism. The tree yields a dark almost opaque gum similar to tragacanth and is used as substitute for katira gum. It is astringent, tonic and laxative. The gum is given in bowel complaints, painful micturation and gonorrhea [1].

The organization for economic corporation and development (OECD) panel of experts defines acute toxicity as "the adverse effect occurring within a short time of (oral) administration of a single dose of a substance or multiple doses given within $24 \mathrm{hrs}$. And subacute toxicity as "the advance effects occurring as result of the repeated daily (oral) dosing of a chemical to experimental annual for part (not exceeding 10\%) of the life span [2]. Although opinions different on the length of exposure. Exposure in a subacute study is generally from 1-3 months. The National Academy of Science (NAS) defines subacute exposure from a few days to 6 months [3]. When these times are translated terms of human exposure, acute toxicity represents life threatening crises of accidental catastrophes and over doses, suicidal attempts acute toxicity, on the other hand, represents daily ingestion or additive or agricultural chemical residues food.

The purpose of toxicity testing is to provide adequate database to make decisions concerning the toxicology properties of chemical and commercial products. In some situations, the purpose is to decide whether a material will be safe. Under the conditions of expected use in other situations, the objective is to establish the safe limits in condition of use. This process is called hazard evaluation and would contribute to the introduction of new industrial chemicals and household products.

Subacute toxicity testing gives the valuable information on the cumulative toxicity of a substance, forget organs, physiological organ and metabolic of a compound at low dose prolonged exposure. A wide variety of adverse effect can be detected. The result from such studies can provide information's which will aid in selecting dose level.

The long term safety level of a compound can be predicted from acute or shorter than subacute studies [4, 5]. Acutely non-toxic compounds may be toxic from prolong exposure, even at low dose level, due to cumulation, changes in enzyme level and disruption of physiological and biochemical homeostasis.

Oral and inhalation subacute studies are generally carried out in three months. In shorter live animals (rodents) and one year in longer lived animals (dogs and monkeys). Subacute plural studies are usually performed in one month or tests. The common routes of administration employed in subacute toxicities studies are oral, dermal and respiratory.

\section{Materials and Methods}

\subsection{Preparation of alcoholic plant extract}

Freshly collected root of ceiba pentandra was dried in shade and pulverized to get a coarse powder. A weighed quantity of the powder (1200g) was passed through sieve number 40 and subjected to hot solvent extraction in a soxhlet apparatus using methanol, at a temperature range of $550 \mathrm{C}$ to $650 \mathrm{C}$. Before and after every extraction the marc was completely dried and weighed. The filtrate was evaporated to dryness at $400 \mathrm{C}$ under 
reduced pressure in a rotary vacuum evaporator. The percentage yield of methanolic extract was $8.83 \% \mathrm{w} / \mathrm{w}$.

\subsection{Experimental animals}

Adult male and female Wistar rats (125-150 g) were used for acute and subacute toxicity study. These animals were kept in polypropylene cages under identical animal house condition and provided with standard pellet and water ad libitum. Each cage contained 3 rats of the same sex with a bedding of husk, and 12-hour light/dark cycles were provided. Environmental conditions were maintained at a temperature of $22^{\circ} \mathrm{C} \pm 2{ }^{\circ} \mathrm{C}$ and a relative humidity of $60 \% \pm 10 \%$.

\subsection{Acute oral toxicity studies}

Toxicity studies conducted as per internationally accepted protocol drawn under OECD No 420 guidelines [6]. The overnight fasted rats were divided into 4 groups, each group consisting of 3 animals. The methanol extract of roots of $C$. pentandra was given separately in various doses $(50,500,1000,2000 \mathrm{mg} / \mathrm{kg})$ by oral route. After administration of the extract, the animals were observed continuously for the first two hours and $24 \mathrm{hrs}$ to detect changes in the behavioural responses and also for tremors, convulsion, salivation, diarrhoea, lethargy, sleep and coma and monitored for any mortality.

\subsection{Subacute toxicity studies}

Four groups of rats were used in subacute toxicity study of methanol extract of roots of C. pendantra and each group consists of 6 rats. The groups and treatment were designed as follows:

Group 1 - Control treated with saline $(2 \mathrm{ml} / \mathrm{kg}$, p.o.)

Group 2 - C. pendantra (100 mg/kg, p.o.)

Group 3 - C. pendantra (400 mg/kg, p.o.)

Group 4 - C. pendantra (750 mg/kg, p.o.)

Six groups of rats received C. pentandra at 100, 400 and $750 \mathrm{mg} / \mathrm{kg}$ (low dose, intermediate dose and high dose) orally for 28 days. The group which served as control received equivalent quantity of normal saline orally. Animals were observed for signs and symptoms, behaviour alteration, food and water intake and body weight changes. All animals were observed twice daily for mortality during the 28 day period of study. The weight of each rat was recorded on day 0 and at weekly intervals throughout the course of the study. The group mean body weights were calculated.

At the end of the 28-day period the animals were fasted overnight. The following morning, each animal was heparinised and blood samples were collected from the orbital sinus. The blood sample was collected after $24 \mathrm{~h}$ of the last doses of alcoholic extracts. 
Haematological analyses were performed in total blood was collected in heparinized funnels and tubes with EDTA The relative blood indices white blood cell count (WBC), red blood cell count (RBC), haemoglobin $(\mathrm{Hb})$, erythrocyte sedimentation rate (ESR), platelets, clotting time and packed cellular volume (PCV) were determined using routine method [7]. In addition, biochemical analyses were performed in serum obtained after centrifugation of total blood without anticoagulants, at $2400 \mathrm{rpm}$ for $15 \mathrm{~min}$. the analysis of blood glucose [8], Cholesterol [10], serum glutamate pyruvate (GPT) [9] and glutamate oxaloacetate transaminase (GOT) [9], alkaline phosphatase, total bilirubin [11], Urea and BUN [12], total protein and albumin [13] and creatinine [14] were estimated in serum. Urine samples were also collected at the end of the study period and analyzed for specific gravity, $\mathrm{pH}$, glucose, proteins, ketones, and occult blood. At the end of 28 days, experiment animals were autopsied and vital organs viz. liver, kidney, spleen, lung, heart and brain were removed and subjected to gross examination and later weighed.

Since liver and kidney are organs of metabolism and excretion, potentially toxic agents are likely to affect them. So, portions of these organs were fixed in buffered $10 \%$ formalin and $5 \mu \mathrm{m}$ thick paraffin sections were made and stained with haemotoxylin and eosin [15] for microscopic examination.

\subsection{Statistical analysis}

The values were expressed as mean \pm SEM. Statistical analysis was performed by one way analysis of variance (ANOVA) followed by Tukey multiple comparison test. $P$ values $<0.05$ were considered as significant.

\section{Results and Discussion}

\subsection{Acute toxicity studies}

Acute toxicity has been defined variously by various experts. The organization for economic cooperation and development (OECD) panel of experts has defined acute toxicity as "the adverse effect occurring within a short time of (oral) administration of a single dose of a substance or multiple doses given within a span of 24 hours.

The purpose of acute toxicity studies is to determine the $\mathrm{LD}_{50}$ values which help in determining the safe dose range at which the drug can be used such that there is no harmful or lethal effect on the animal.

No mortalities had occurred during acute toxicity studies show the $C$. pentandra did not produce death even at high dose $(2 \mathrm{~g} / \mathrm{kg})$ and so it is found to be safe.

\subsection{Subacute toxicity studies}

It was observed that the animals fed with extract of $C$. pendantra were healthy. No unusual changes in behavior or in locomotor activity, no ataxia, and no signs of 
intoxication were observed during the 28-day period. No differences were found in growth between the control group and the animals fed with different levels of the extract of $C$. pentandra, (Table 1). No change in fur coating, eyes and respiratory functions. There was no significant difference in the food and water consumption between the treatment and control groups.

Table 1. Changes in body weight of rats following treatment with different doses of MCP.

\begin{tabular}{|c|c|c|c|}
\hline Treatment & $\begin{array}{c}\text { Dose } \\
(\mathrm{mg} / \mathrm{kg})\end{array}$ & \multicolumn{2}{|c|}{ Body weight (gm) } \\
\hline \multirow[t]{2}{*}{ Control } & \multirow[t]{2}{*}{-} & Initial & $\begin{array}{c}\text { After } 28 \text { days } \\
\text { treatment }\end{array}$ \\
\hline & & $160 \pm 0.9$ & $183 \pm 1.4$ \\
\hline \multirow{3}{*}{$\mathrm{MCP}$} & 100 & $169 \pm 1.1$ & $189 \pm 1.7$ \\
\hline & 400 & $165 \pm 0.7$ & $190 \pm 1.3$ \\
\hline & 750 & $158 \pm 1.4$ & $192 \pm 1.6$ \\
\hline
\end{tabular}

Haematological parameters, RBC, WBC (Total), Hb, ESR, platelets, clotting time and $\mathrm{PCV}$, in both control and experimental rats, were not significantly different $(P>.05)$ for $C$. pentandra (Table 2). All values were found to be within the normal range for rats, and there were no differences between the groups.

Table 2. Effect of MCP on haemotological changes in rats.

\begin{tabular}{|c|c|c|c|c|c|c|c|c|}
\hline $\begin{array}{l}\text { Treat- } \\
\text { ment }\end{array}$ & $\begin{array}{c}\text { Dose } \\
(\mathrm{mg} /\end{array}$ & $\begin{array}{c}\mathrm{Hb} \\
(\mathrm{gm} \%)\end{array}$ & $\begin{array}{l}\mathrm{RBC} \\
\left(10^{6} /\right. \\
\left.\mathrm{mm}^{3}\right)\end{array}$ & $\begin{array}{c}\text { Total } \\
\text { WBC } \\
\left(10^{3} /\right. \\
\left.\mathrm{mm}^{3}\right)\end{array}$ & $\begin{array}{l}\text { ESR } \\
(\mathrm{mm} / \\
\left.1^{\text {st }} \mathrm{hr}\right)\end{array}$ & $\begin{array}{c}\text { Platelets } \\
(\mathrm{K} / \mu \mathrm{L})\end{array}$ & $\begin{array}{l}\text { Clotting } \\
\text { time } \\
\text { (sec.) }\end{array}$ & $\begin{array}{r}\text { PCV } \\
(\%)\end{array}$ \\
\hline Control & - & $\begin{array}{c}12.85 \pm \\
0.56\end{array}$ & $\begin{array}{c}4.02 \pm \\
0.58\end{array}$ & $\begin{array}{c}8.10 \pm \\
0.24\end{array}$ & $\begin{array}{c}3.05 \pm \\
0.06\end{array}$ & $\begin{array}{l}595 \pm \\
19.18\end{array}$ & $\begin{array}{c}129.64 \pm \\
1.37\end{array}$ & $\begin{array}{l}38 \pm \\
2.83\end{array}$ \\
\hline \multirow{3}{*}{$\mathrm{MCP}$} & 100 & $\begin{array}{c}13.17 \pm \\
0.35\end{array}$ & $\begin{array}{c}4.15 \pm \\
0.25\end{array}$ & $\begin{array}{c}7.86 \pm \\
0.17\end{array}$ & $\begin{array}{c}3.12 \pm \\
0.07\end{array}$ & $\begin{array}{l}580 \pm \\
23.24\end{array}$ & $\begin{array}{c}134.83 \pm \\
2.20\end{array}$ & $\begin{array}{l}42 \pm \\
1.36\end{array}$ \\
\hline & 400 & $\begin{array}{c}14.08 \pm \\
0.62\end{array}$ & $\begin{array}{c}4.37 \pm \\
0.32\end{array}$ & $\begin{array}{c}8.06 \pm \\
0.26\end{array}$ & $\begin{array}{c}3.10 \pm \\
0.10\end{array}$ & $\begin{array}{l}595 \pm \\
26.58\end{array}$ & $\begin{array}{c}128.33 \pm \\
0.78\end{array}$ & $\begin{array}{l}46 \pm \\
2.66\end{array}$ \\
\hline & 750 & $\begin{array}{c}13.94 \pm \\
0.94\end{array}$ & $\begin{array}{c}4.46 \pm \\
0.35\end{array}$ & $\begin{array}{l}7.93 \pm \\
0.23\end{array}$ & $\begin{array}{c}3.04 \pm \\
0.15\end{array}$ & $\begin{array}{l}605 \pm \\
23.59\end{array}$ & $\begin{array}{c}126.10 \pm \\
2.34\end{array}$ & $\begin{array}{l}40 \pm \\
2.56\end{array}$ \\
\hline
\end{tabular}

$N=6$ animals in each group; values are expressed as mean \pm SEM.

$N S=$ Statistically not significant.

Data were analyzed by one-way ANOVA followed by Tukey multiple comparison test.

The levels of serum analytes, such as glucose, cholesterol, alkaline phosphatase, total bilirubin, urea, BUN, total protein, and creatinine were not significantly different between the control and the experimental groups of rats $(P>0.05)$ when fed with $C$. pentandra (Tables 3 and 4). In other hand, serum glutamate pyruvate (GPT) and glutamate 
oxaloacetate transaminase (GOT) were significantly raised when compared to control group rats. Analysis of the urinary metabolite levels (specific gravity, $\mathrm{pH}$, glucose, proteins, blood cells, and ketones) showed trace or no presence of these in both control and experimental animals fed with extract (Table 5).

Table 3. Effect of MCP on biochemical parameters in rats.

\begin{tabular}{cccccccc}
\hline Treatment & $\begin{array}{c}\text { Dose } \\
(\mathrm{mg} / \mathrm{kg})\end{array}$ & $\begin{array}{c}\text { Glucose } \\
(\mathrm{mg} \%)\end{array}$ & $\begin{array}{c}\text { Cholesterol } \\
(\mathrm{mg} \%)\end{array}$ & $\begin{array}{c}\text { SGPT } \\
(\mathrm{U} / \mathrm{L})\end{array}$ & $\begin{array}{c}\text { SGOT } \\
(\mathrm{U} / \mathrm{L})\end{array}$ & $\begin{array}{c}\text { ALP } \\
(\mathrm{U} / \mathrm{L})\end{array}$ & $\begin{array}{c}\text { Total Bil. } \\
(\mathrm{mg} \%)\end{array}$ \\
\hline Control & - & $86 \pm 1.5$ & $118 \pm 1.70$ & $130.8 \pm 2.0$ & $62.5 \pm 1.3$ & $192 \pm 2.1$ & $0.83 \pm 0.04$ \\
& 100 & $94 \pm 2.10^{\mathrm{a}}$ & $110 \pm 1.65$ & $124.6 \pm 2.9$ & $58.0 \pm 1.7$ & $189 \pm 1.96$ & $0.79 \pm 0.07$ \\
$\mathrm{MCP}$ & 400 & $89 \pm 1.8$ & $108 \pm 1.98$ & $118.5 \pm 1.4^{\mathrm{b}}$ & $65.0 \pm 2.4$ & $190 \pm 1.75$ & $0.86 \pm 0.02$ \\
& 750 & $97 \pm 2.0^{\mathrm{b}}$ & $113 \pm 2.86$ & $148.0 \pm 2.7^{\mathrm{a}}$ & $76.0 \pm 2.0^{\mathrm{a}}$ & $183 \pm 2.0$ & $0.84 \pm 0.06$ \\
\hline
\end{tabular}

$N=6$ animals in each group; Values are expressed as mean \pm SEM.

${ }^{\mathrm{a}} P<0.01 ;{ }^{\mathrm{b}} P<0.05$ vs control.

$N S=$ Statistically not significant.

Data were analyzed by one-way ANOVA followed by Tukey multiple comparison test.

Table 4. Effect of MCP on biochemical parameters in rats.

\begin{tabular}{cccccc}
\hline Treatment & $\begin{array}{c}\text { Dose } \\
(\mathrm{mg} / \mathrm{kg})\end{array}$ & $\begin{array}{c}\text { Urea } \\
(\mathrm{mg} \%)\end{array}$ & $\begin{array}{c}\text { BUN } \\
(\mathrm{mg} \%)\end{array}$ & $\begin{array}{c}\text { Creatinine } \\
(\mathrm{mg} \%)\end{array}$ & $\begin{array}{c}\text { Total protein } \\
(\mathrm{gm} \%)\end{array}$ \\
\hline Control & - & $31.5 \pm 1.14$ & $23.65 \pm 2.13$ & $0.8 \pm 0.10$ & $8.0 \pm 1.10$ \\
& 100 & $34.7 \pm 1.43$ & $25.97 \pm 1.17$ & $0.7 \pm 0.02$ & $7.5 \pm 1.06$ \\
MCP & 400 & $30.5 \pm 1.57$ & $27.24 \pm 1.78$ & $0.8 \pm 0.07$ & $8.2 \pm 1.20$ \\
& 750 & $39.2 \pm 2.0$ & $26.16 \pm 2.34$ & $0.9 \pm 0.09$ & $7.8 \pm 1.28$ \\
\hline
\end{tabular}

$N=6$ animal in each group ; Values are expressed as mean \pm SEM.

$N S=$ Statistically not significant.

Data were analyzed by one-way ANOVA followed by Tukey multiple comparison test.

Table 5. Effect of MCP on urine analysis in rats.

\begin{tabular}{cccccccc}
\hline Treatment & $\begin{array}{c}\text { Dose } \\
(\mathrm{mg} / \mathrm{kg})\end{array}$ & $\begin{array}{c}\text { Specific } \\
\text { gravity }\end{array}$ & $\mathrm{pH}$ & Glucose & Protein & $\begin{array}{c}\text { Ketone } \\
\text { bodies }\end{array}$ & $\begin{array}{c}\text { Blood } \\
\text { cells }\end{array}$ \\
\hline Control & - & $1.02 \pm 0.04$ & $6.72 \pm 0.19$ & NIL & NIL & NIL & NIL \\
& 100 & $1.03 \pm 0.06$ & $6.58 \pm 0.18$ & NIL & NIL & NIL & NIL \\
MCP & 400 & $1.04 \pm 0.03$ & $6.59 \pm 0.16$ & NIL & NIL & NIL & NIL \\
& 750 & $1.06 \pm 0.02$ & $6.25 \pm 0.24$ & NIL & NIL & NIL & NIL \\
\hline
\end{tabular}

$N=6$; Values were expressed as mean \pm SEM.

$N S=$ Statistically not significant.

Data were analyzed by one-way ANOVA followed by Tukey multiple comparison test.

Table 6 depicts the organ-to-body mass ratios of animals at the end of 28 days' feeding. No abnormal changes were observed in organ mass with respect to body mass of extract of $C$. pentandra fed rats in comparison with controls. Observations of gross 
pathology immediately after dissection, on rats of all groups were found to be uniformly healthy, lacking in any apparent pathological abnormalities.

Table 6. Effect of methanol extract of MCP on weight (GM) of vital organs of rats.

\begin{tabular}{cccccccc}
\hline $\begin{array}{c}\text { Treat- } \\
\text { ment }\end{array}$ & $\begin{array}{c}\text { Dose } \\
(\mathrm{mg} / \mathrm{kg})\end{array}$ & Liver & Kidney & Heart & Lungs & Spleen & Brain \\
\hline Control & - & $4.02 \pm 0.17$ & $1.30 \pm 0.19$ & $0.72 \pm 0.03$ & $1.72 \pm 0.14$ & $0.90 \pm 0.07$ & $1.85 \pm 0.16$ \\
& 100 & $4.05 \pm 0.30$ & $1.33 \pm 0.17$ & $0.76 \pm 0.04$ & $1.65 \pm 0.12$ & $0.97 \pm 0.08$ & $1.96 \pm 0.12$ \\
$\mathrm{MCP}$ & 400 & $4.12 \pm 0.16$ & $1.37 \pm 0.34$ & $0.69 \pm 0.02$ & $1.70 \pm 0.10$ & $1.06 \pm 0.06$ & $2.0 \pm 0.14$ \\
& 750 & $3.97 \pm 0.13$ & $1.33 \pm 0.20$ & $0.74 \pm 0.05$ & $1.76 \pm 0.16$ & $1.15 \pm 0.18$ & $1.72 \pm 0.25$ \\
\hline
\end{tabular}

$N=6$ animal in each group; Values are expressed as mean \pm SEM.

$N S=$ Statistically not significant.

Data were analyzed by one-way ANOVA followed by Tukey multiple comparison test.

Histopathological examination of the liver and kidneys in the control and the $C$. pentandra extract fed groups showed no differences, indicating that feeding these $C$. pentandra extract of roots at these levels to the rats did not result in any adverse toxicological effect on these organs (Figs. 1 and 2).

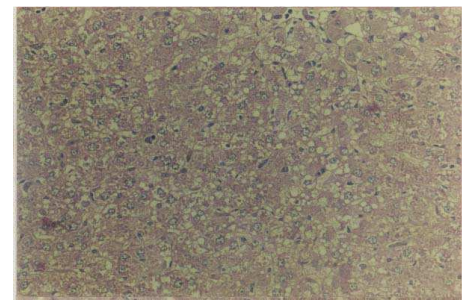

(a)

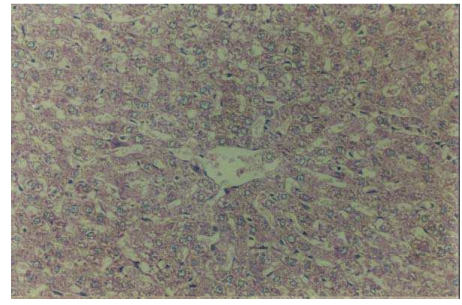

(c)

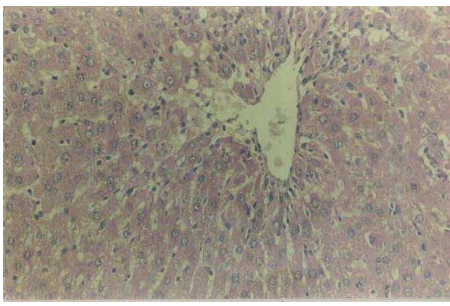

(b)

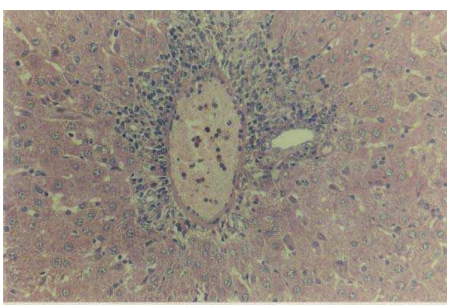

(d)

Fig. 1. Histopathological studies of liver - subacute toxicity studies; (a) section of liver treated with normal saline, (b) section of liver treated with MCP $(100 \mathrm{mg} / \mathrm{kg})$, (c) section of liver treated with MCP (400 mg/kg), (d) section of liver treated with MCP $(750 \mathrm{mg} / \mathrm{kg}$ ). 


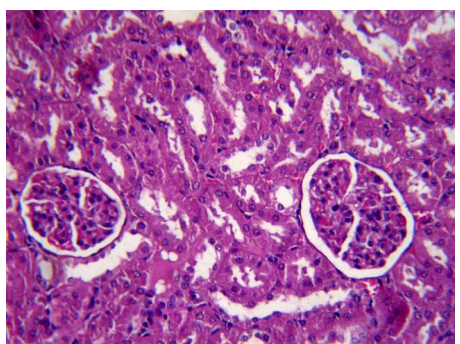

(a)

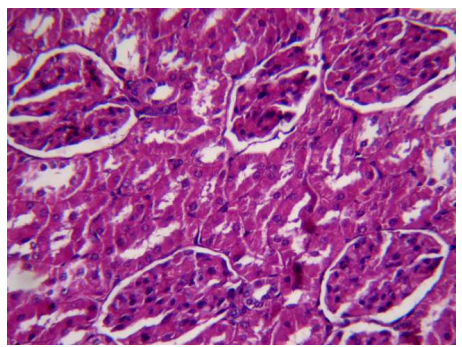

(c)

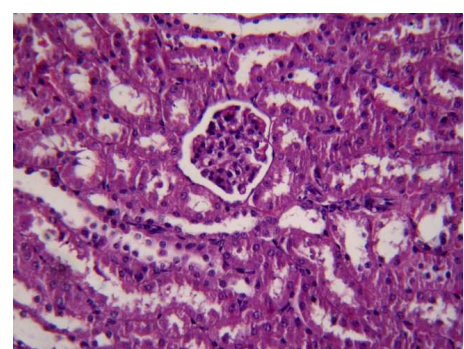

(b)

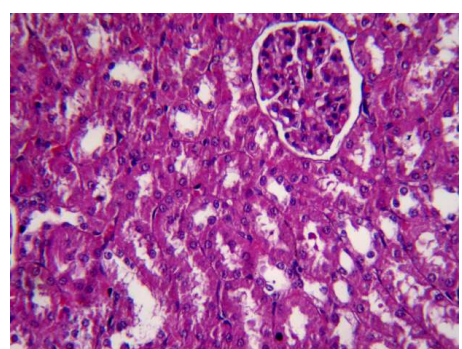

(d)

Fig. 2. Histopathological studies of kidney - subacute toxicity studies; (a) section of kidney treated with normal saline, (b) section of kidney treated with MCP (100 mg/kg), (c) section of kidney treated with MCP (400 mg/kg), (d) section of kidney treated with MCP (750 $\mathrm{mg} / \mathrm{kg})$.

The purpose of this study was to look at the toxicity profile of the C. pentandra. A 28day study is considered a subacute study, which is well accepted for eliciting any toxicity on long-term feeding. It gives valuable information on the cumulative toxicity of a substance on target organs or physiological and metabolic effects of the compound at low dose on prolonged exposure. A wide variety of adverse effects can be detected from subacute toxicity studies. The result from such studies can provide information, which will aid in selecting dose level. The long term safety level of a compound can be predicted from acute or shorter than subacute studies. Acutely nontoxic compounds may be toxic on prolonged exposure even at low dose levels due to cumulation, changes in enzyme level and disruption of physiological and biochemical homeostasis. Subacute studies are generally carried out in few days to three months.

According to Onyenyili and co-workers [15], anaemia following administration of an agent can be as a result of lysis of blood cells and/or inhibition of blood cell synthesis by the active constituents of the extract, and decrease in hematological parameters in experimental animals has been associated with anemia [16]. There was no significant change in haematological parameters in the extracts-treated animals compared to the control (Table 2), which indicates that there is no lysis of blood cells and/or inhibition in blood cells synthesis by the active constituents of $C$. pentandra extract. The above results suggest the non toxicity of $C$. pentandra in rats. 
Clinical chemistry parameters were statistically not significant in comparison to control groups except SGOT \& GPT levels. However, there was no alteration shown in histopathological studies of liver tissues. They are confirming the absence of adverse effects. No adverse effect has been observed in renal function test also. No mortality was recorded in rats treated with higher dose of $750 \mathrm{mg} / \mathrm{kg}$. The toxicity study of the drug reflected the innocuous nature of this plant extracts on hepatic, renal and haemopoetic system even at high dose.

Rats treated with the various doses of the extract $(100,400$ and $750 \mathrm{mg} / \mathrm{kg}$ ) had no significant change in body weight. No statistically significant differences existed in the absolute and relative weights of all the isolated organs between the treated and the control rats (Table 6). Kluwe documented that the absolute organ weight has been observed to be a relative sensitive indicator of nephrotoxicity for known nephrotoxicants [17]. An increase in kidney weight (either absolute or relative) indicates nephrotoxicity [17]. The C. pentandra did not induce any toxic effect on the kidneys and the other organs going by this indicator, since the absolute and relative weights of the organs were not significantly different from control values.

Microscopic data together with the data of macroscopic evaluation of the animals' organ showed that both test and control groups were practically healthy. According to the data of histological examination, no toxic or allergic effects of $C$. pentandra were detected in the test group. No local irritating effects of the drug preparation were observed in the test group during the study period. Our experiments showed that $C$. pentandra has a safe.

In histopathological studies, the liver of treated animals showed normal histological feature at 100,400 and $750 \mathrm{mg} / \mathrm{kg}$. No degeneration of hepatocycle, focal steatosis, congestion of central vein and inflammation of portal tract when compared with control animals. The kidney of treated rats showed normal glomeruli and there is no necrosis of tubular epithelium in the kidney. Gross examination of liver and kidney on histology did not reveal any abnormalities. Thus, it was concluded that $C$. pentandra did not produce any toxic effect in male albino rats.

\section{Conclusions}

No mortality was recorded in experimental animals treated with the drug orally at a dose of $750 \mathrm{mg} / \mathrm{kg}$. The toxicity study of the drug reflected the innocuous nature of this plant extracts on hepatic, renal and haemopoetic system even at high dose level of daily administration for 28 days in rats. From the above results, it is clear that the $C$. pentandra did not produced toxic effect in rats.

\section{References}

1. K. R. Kirtikar and B. D. Basu, Indian medicinal plants, Vol 1 (International book distributors, Dehardun, India, 1999) pp. 358-360.

2. J. P. Lee and R. L. Dixon, Env. Health Perspect. 24, 117 (1978).

http://dx.doi.org/10.1289/ehp.7824117

PMid:17539139 PMCid:1637207 


\section{Acute and Subacute Toxicity}

3. J. A. Maclachlan and R. L. Dixon, Advances in modern toxicology: new concepts in safety evaluation, Vol. Part 1 (Hemisphere publishing, Washington D.C., 1976) pp. 423-448.

4. Ministry of Health and Welfare, Canada health protection branch: The testing of chemicals for carcinogenecity, mutagenecity and Teratogencity (1977).

5. J. S. Perry, The ovarian cycle of mammals, Vol 13 (Oliver and Boyd, Edinburgh University Review Biology, 1971).

6. The Organization of Economic Co-Operation and Development (OECD), The OECD guideline for testing of chemicals: 420-acute oral toxicity, OECD, Paris (1001) pp. 1-14.

7. J. V. Docie, Practical haemotology (J\&A Churchill Ltd., London, 1958) pp. 38-42.

8. A. S. G. Hugget and D A Nixon, The Lancet 270 (6991), 368 (1957). http://dx.doi.org/10.1016/S0140-6736(57)92595-3

9. D R Wybenga, V. J. Pileggi, P. H. Dirstine, and J. D. Giorgio, J .Clin. Chem., 16 (12), 980 (1970). PMID: 4098216

10. S. Reitman and S. Frankel, Am. J. Clin. Pathol. 28, 53 (1957).

11. H. T. Mallay and K. A. Evelyn, J. Biol. Chem. 119, 481 (1937).

12. S. Natelson, Micro techniques of clinical chemistry for the routine laboratory (Thomas Springfield, Dilliners, 1957) p. 381.

13. O. H. Lowry, N. J. Rosebrough, and A. L. Farr, and R. J. Randall, J. Biol. Chem. 193, 265 (1951).

14. R. J. Henry, Clinical chemistry principles and techniques, 2nd ed. (Harper and Row Publication, Newyork, 1974) p. 225.

15. R. D. Lillie, Histopathological techniques and practical histochemistry (McGraw Hill Book Co., New York, 1965) p. 176.

16. P. A. Onyeyilli, C. L. Iwuoha, and J. A. Akinniyi, West Afr. J. Pharmacol. Drug Res. 14, 27 (1998).

17. W. M. Kluwe, Toxicol. Appl. Pharmacol. 57 (3), 414 (1981). http://dx.doi.org/10.1016/0041-008X(81)90239-8 